\title{
Bacteriological Quality of Raw Milk in Beni-Suef Governorate, Egypt
}

\author{
Arafa M.S. Meshref' • Gamal M. Hassan' ${ }^{1}$ Mostafa A. Tamam²
}

Received: 29 October 2021 | Accepted: 08 November 2021 | Published online: 26 December 2021

\begin{abstract}
1 Food Hygiene Department, Faculty of Veterinary Medicine, Beni-Suef University, Beni Suef 62511, Egypt.

2 Postgraduate at Food Hygiene Department, Faculty of Veterinary Medicine, BeniSuef University, Beni Suef 62511, Egypt.
\end{abstract}

\section{Correspondence Mostafa A. Tamam,} Postgraduate at Food Hygiene Department, Faculty of Veterinary Medicine, Beni-Suef University, Beni-Suef 62511, Egypt.

Email:

mostafaagamy1908@gmail.com

\begin{abstract}
The aim of the study was directed to investigate the bacteriological quality of raw milk in Beni-Suef governorate, Egypt by conventional bacteriological methods. A total of 125 raw milk samples including 25 bulk tank milk of large dairy herds, 25 bulk tank milk of large dairy herd (after improving the environmental and pre milking sanitation), 25 milk samples from smallholder dairy herds, and 50 samples from milk shops, were collected from Beni Suef governorate, Egypt. All samples were examined for Total Bacterial Count (TBC), Psychrotrophic Count (PC), Total Coliform Count (TCC), Fecal coliform (FC), and E. coli. The mean values of TBC were $1.53 \times 107 \pm 6.27 \times 106,2 \times 106 \pm 6.58 \times 105$, $7.85 \times 106 \pm 3.95 \times 106,1.65 \times 107 \pm 4.32 \times 106 \mathrm{cfu} / \mathrm{ml}$, respectively. The mean values of PC were $2.83 \times 105 \pm 6.85 \times 104,8.98 \times 104 \pm 2.67 \times 104,6.85 \times 104$ $\pm 1.24 \times 104$, and $1.72 \times 105 \pm 3.79 \times 104 \mathrm{cfu} / \mathrm{ml}$, respectively. The mean values of TCC were $3.89 \times 105 \pm 1.38 \times 105,5.3 \times 104 \pm 3.07 \times 104,6.4 \times 105 \pm 1.57 \times 105$, $2.2 \times 106 \pm 6.87 \times 105 \mathrm{MPN} / \mathrm{ml}$, respectively. The mean values of FC were 9.20 $\times 103 \pm 1.82 \times 103,6.36 \times 102 \pm 1.9 \times 102,6.04 \times 103 \pm 1.57 \times 103,6.5 \times 103 \pm$ $1.08 \times 103 \mathrm{MPN} / \mathrm{ml}$, respectively. The mean values of $E$. coli were $2.57 \times 103 \pm$ $6.11 \times 102,3.8 \times 102 \pm 2.48 \times 102,3.89 \times 103 \pm 7.36 \times 102,4.15 \times 103 \pm 5.44 \times$ $102 \mathrm{cfu} / \mathrm{ml}$, respectively. The results showed that improving sanitation significantly improved milk quality. High bacterial counts in raw milk especially E. coli constitutes a public health hazard to the consumers and emphasize the great need for an improved hygienic standard.

\section{Keywords}

E. Coli, Fecal Coliform, Psychotropic Bacteria, Raw Milk, Total Bacterial Count, Total Coliform Count,
\end{abstract}

\section{Introduction}

Milk is the most significant part of the human diet, and it is utilized in a variety of ways as food. It is not only natural nourishment for newborns, but also a source for a variety of dairy products consumed by humans. It plays a prominent role in meeting the essential human dietary requirements (protein, lactose, fat, minerals and vitamins) (Dairy Facts 2003). The highest demanded perishable food products worldwide is milk. In 2019, milk global production increased $1.4 \%$, in total 852 million tones as reported by FAO (2020). Although raw milk from a healthy udder contains very few bacteria, it picks up so many bacteria from the time it leaves the teats of the cow until it is used for further processing (Tassew and Seifu 2011).

Raw milk is produced mainly by solitary individuals in small farms that lack proper sanitary measures and 
may be either consumed fresh, manufactured into dairy products or sell in retail markets that alarming as a major source of public hazard and represents a serious human health problem (El-Sayed et al. 2011). TBC is used to estimate the quality of raw milk, and has become one of the most accepted criteria for grading milk (Mhone et al. 2011). The legalized limits proposed by the Egyptian standards, recommended by the Egyptian organization for standardization and quality "EOSQ", SPC stated that raw milk must not exceed $1 \times 10^{5} \mathrm{cfu} / \mathrm{ml}$ (ES 2005).

Psychrotrophic bacterial contamination of raw milk is one of the key factors determining the quality of processed dairy products due to the heat-stable enzymes produced by these bacteria (Zhang 2020). Many countries use coliforms and E. coli as indicators of sanitary quality of foods and have set limits for raw milk, world widely. Coliforms and E. coli were found in different types of raw milk, with raw milk contained indicator levels $>10^{3} \mathrm{cfu} / \mathrm{ml}$ have been attributed mostly to unsanitary conditions/production (Metz et al. 2020).

High bacterial count in raw milk represents a public health hazard to the consumers and necessitates the need for improving the application of hygienic standards. In this regard, this study was conducted to investigate the bacteriological quality of raw milk in Beni-Suef governorate.

\section{Materials and Methods}

\subsection{Collection of samples}

A total of 125 raw milk samples including 25 bulk tank milk of large dairy herds, 25 bulk tank milk of large dairy herd (after improving the environmental and pre milking sanitation), 25 milk samples from smallholder dairy producers and 50 samples from milk shops were collected from Beni-Suef governorate. The sanitation treatment consisted of washing of udder and teats, drying of udder, washing of milker's hand with tape water and soap, teat dipping before milking. Milk was directly cooled after milking, and milk samples were collected in sterilized tubes.

\subsection{Preparation of samples}

At first, the milk was thoroughly mixed just before sampling using sterile plunger (in case of small tanks) or mechanical agitator (in case of large tank) and the milk samples were taken in sterile sampling bottles under complete aseptic precaution. Each bottle was labeled to denote the date, time of sampling, number and the name of the farm. The samples were transferred directly to the laboratory in an insulated icebox without delay to be immediately examined.

Market raw milk samples were subjected to storch's test lampert (1975) to exclude all samples proved to be heat treated.

\subsection{Microbiological examination.}

2.3.1 Total bacterial count (TBC): was performed according to (APHA 1992a) using plate count agar (Oxoid, UK) for $48 \pm 3 \mathrm{~h}$ after incubation at $32 \pm 1{ }^{\circ} \mathrm{C}$.

2.3.2. Psychrotrophic bacteria count PC: was performed according to (APHA 1992a).

2.3.3. Total coliform count using lauryl sulphate tryptose (LST) broth (APHA 1992a).

\subsubsection{Fecal coliform count by using EC broth (APHA 1992a).}

2.3.5. E.coli count by using Eosine Methylene Blue agar (EMB) (APHA 1992a). 


\section{Results}

Table 1. Statistical analytical results of Total Bacterial Count (cfu/ml) in the examined samples

\begin{tabular}{cccccc}
\hline Samples & No. of sample & Min. & Max. & Mean & \pm SEM \\
\hline Bulk tank milk & 25 & $1.1 \times 10^{5}$ & $9 \times 10^{7}$ & $1.53 \times 10^{7}$ & $6.27 \times 10^{6}$ \\
\hline Bulk tank milk (after sanitation) & 25 & $1.02 \times 10^{5}$ & $1.1 \times 10^{7}$ & $2 \times 10^{6}$ & $6.58 \times 10^{5}$ \\
\hline Smallholder dairy herd & 25 & $5.7 \times 10^{4}$ & $9.5 \times 10^{7}$ & $7.85 \times 10^{6}$ & $3.95 \times 10^{6}$ \\
\hline Milk shops & 50 & $7 \times 10^{4}$ & $9.5 \times 10^{7}$ & $1.65 \times 10^{7}$ & $4.32 \times 10^{6}$ \\
\hline
\end{tabular}

Table 2. Statistical analytical results of Psychrotrophic bacterial count (cfu/ml) in the examined milk samples

\begin{tabular}{cccccc}
\hline Samples & No. of sample & Min. & Max. & Mean & \pm SEM \\
\hline Bulk tank milk & 25 & $1.17 \times 10^{4}$ & $1.5 \times 10^{6}$ & $2.83 \times 10^{5}$ & $6.85 \times 10^{4}$ \\
\hline Bulk tank milk (after treatment) & 25 & $1 \times 10^{4}$ & $7 \times 10^{5}$ & $8.98 \times 10^{4}$ & $2.67 \times 10^{4}$ \\
\hline Smallholder dairy herd & 25 & $1.02 \times 10^{4}$ & $2.97 \times 10^{5}$ & $6.85 \times 10^{4}$ & $1.24 \times 10^{4}$ \\
\hline Milk shops & 50 & $1 \times 10^{4}$ & $9.5 \times 10^{6}$ & $1.72 \times 10^{5}$ & $3.79 \times 10^{4}$
\end{tabular}

Table 3. Statistical analytical results of total coliform count (MPN/ml) in the examined samples

\begin{tabular}{cccccc}
\hline Samples & No. of sample & Min. & Max. & Mean & \pm SEM \\
\hline Bulk tank milk & 25 & $1.5 \times 10^{3}$ & $2.1 \times 10^{6}$ & $3.89 \times 10^{5}$ & $1.38 \times 10^{5}$ \\
\hline Bulk tank milk (after sanitation) & 25 & $1.5 \times 10^{3}$ & $7.5 \times 10^{5}$ & $5.3 \times 10^{4}$ & $3.07 \times 10^{4}$ \\
\hline Smallholder dairy herd & 25 & $2.1 \times 10^{3}$ & $2.1 \times 0^{6}$ & $6.4 \times 10^{5}$ & $1.57 \times 10^{5}$ \\
\hline Milk shops & 50 & $1.5 \times 10^{3}$ & $2.1 \times 10^{7}$ & $2.2 \times 10^{6}$ & $6.87 \times 10^{5}$ \\
\hline
\end{tabular}

Table 4. Statistical analytical results of fecal coliform count (MPN/ml) in the examined samples

\begin{tabular}{cccccc} 
Samples & No. of sample & Min. & Max. & \multicolumn{1}{c}{ Mean } & \pm SEM \\
\hline Bulk tank milk & 25 & $2.1 \times 10$ & $2.4 \times 10^{4}$ & $9.20 \times 10^{3}$ & $1.82 \times 10^{3}$ \\
\hline Bulk tank milk (after sanitation) & 25 & $1.5 \times 10$ & $4.3 \times 10^{3}$ & $6.36 \times 10^{2}$ & $1.9 \times 10^{2}$ \\
\hline Smallholder dairy herd & 25 & $2.4 \times 10$ & $2.4 \times 10^{4}$ & $6.04 \times 10^{3}$ & $1.57 \times 10^{3}$ \\
\hline Milk shops & 50 & $1.5 \times 10^{1}$ & $2.4 \times 10^{4}$ & $6.5 \times 10^{3}$ & $1.08 \times 10^{3}$ \\
\hline
\end{tabular}

Table 5. Statistical analytical results of E.coli count (MPN/ $\mathrm{ml}$ ) in the examined samples

\begin{tabular}{cccccc} 
Samples & No. of sample & Min. & Max. & Mean & \pm SEM \\
\hline Bulk tank milk & 25 & $<3$ & $9.3 \times 10^{3}$ & $2.57 \times 10^{3}$ & $6.11 \times 10^{2}$ \\
\hline Bulk tank milk (after treatment) & 25 & $<3$ & $9 \times 10^{3}$ & $3.8 \times 10^{2}$ & $2.48 \times 10^{2}$ \\
\hline Smallholder dairy herds & 25 & $<3$ & $9.5 \times 10^{3}$ & $3.89 \times 10^{3}$ & $7.36 \times 10^{2}$ \\
\hline Milk shops & 50 & $<3$ & $1.5 \times 10^{4}$ & $4.15 \times 10^{3}$ & $5.44 \times 10^{2}$
\end{tabular}

\section{Discussion.}

It is evident from the results recorded in (Table 1) that the mean values of the total bacterial count (TBC) of milk obtained from bulk tank milk, bulk tank milk (after treatment), smallholder dairy herds and milk shops were $1.53 \times 10^{7} \pm 6.27 \times 10^{6}, 2 \times 10^{6} \pm 6.58 \times 10^{5}$, $7.85 \times 10^{6} \pm 3.95 \times 10^{6}, 1.65 \times 10^{7} \pm 4.32 \times 10^{6} \mathrm{cfu} / \mathrm{ml}$ respectively. Lower results of count were previously detected by Dhuol and Osman 2014; El-Leboudy et al. 2014; Chimuti et al. 2016; Ferdous et al. 2017; Lan et al. 2017; Bousbia et al. 2018; Hahne et al. 2019; Chorfi et al. 2020; Tobar-Delgado et al. 2020; Deepthi and Siriwardhana 2021 for farm raw milk; and Gomaa et al. 2008; El-Diasty and El-
Kaseh 2009; Belli et al. 2013; Mekuria et al. 2014; Ntuli et al. 2016; El-Leboudy et al. 2017; Tekilegiorgis et al. 2018; Rai et al. 2020 for market samples. Higher results were mentioned by AbouDawood 2005; El-Zubeir and Ahmed 2007; Worku et al. 2012; Bauzad et al. 2019 for farm raw milk; and Hossain et al. 2011; Meshref 2013; Tesfay et al. 2013; Banik et al. 2014; Ibrahim et al. 2015; Kuma et al. 2015; Ebissa and Aki 2017; Bouymajane et al. 2019 for markets samples; and agree with Dahal et al. 2010; Titouche et al. 2016; Yeserah 2019; Ebissa and Aki 2017; El- Shinawy et al. 2020 for farm raw milk; Ombarak and Elbagory 2015; Senarth et al. 2017; Mchiouer 
et al. 2017; Acharya et al. 2018 for markets milk samples.

The Results illustrated in (Table 2) revealed that the mean values of the Psychrotrophic bacterial count (PC) in raw milk samples were $2.83 \times 10^{5} \pm 6.85 \times 10^{4}$, $8.98 \times 10^{4} \pm 2.67 \times 10^{4}, 6.85 \times 10^{4} \pm 1.24 \times 10^{4}, 1.72$ $\mathrm{x} 10^{5} \pm 3.79 \times 10^{4} \mathrm{cfu} / \mathrm{ml}$ in the examined milk obtained from bulk tank milk, bulk tank milk (after treatment), smallholder dairy herds and milk shops respectively. Lower results were mentioned by Chye et al. 2004; Pinto et al. 2006; Kumerasan et al. 2007; Ibrahim et al. 2008; Torkar and Teger 2008; Cempírková and Mikulová 2009; Lingathurai and Vellathurai 2013; Yuan et al. 2017; Ribeiro Júnior et al. 2018 for farm raw milk; and Kumerasan et al. 2007; Hossain et al. 2011; Elshaghabee et al. 2017 for market samples. Higher results were recorded by Amer et al. 2008 Nörnberg et al. 2010 for farm raw milk; and Pinto et al. 2006; Amer et al. 2008 for market milk samples while similar results were recorded by Saad et al. 2013; Hahne et al. 2019.

The obtained results in (Table 3) showed that the mean values of total coliform count (TCC) in raw milk samples were $3.89 \times 10^{5} \pm 1.38 \times 10^{5}, 5.3 \times 10^{4} \pm$ $3.07 \times 10^{4}, 6.4 \times 10^{5} \pm 1.57 \times 10^{5}, 2.2 \times 10^{6} \pm 6.87 \times 10^{5}$ MPN/ $\mathrm{ml}$ in the examined milk obtained from bulk tank milk, bulk tank milk (after treatment), smallholder dairy herds and milk shops respectively. Lower results in farm raw milk were previously recorded by Tesfay et al. 2013; El-Leboudy et al. 2014; M'hamdi et al. 2018; Nordin et al. 2019; Yeserah 2019; El- Shinawy et al. 2020; while Lower results in markets milk recoded by Ibrahim et al. 2015; El-Kholy et al. 2015; Ntuli et al. 2016; ElLeboudy et al. 2017; Tekilegiorgis 2018; Koirala et al. 2018; El-Kholy et al. 2018; higher results were reported by El-Diasty and El-Kaseh 2007; Saleh et al. 2013; Bousbia et al. 2018; Fathi et al. 2019 for farm samples; and El-Diasty and El- Kaseh 2009; Sheha 2014; Oluwafemi and Lawal 2015; Abd ElEllah 2017 and Senarath et al. 2017 for market raw milk samples. The obtained results agree with those of Ali 2004; Sraïri et al. 2006; Ferdous et al. 2017; Mchiouer et al. 2017 for farms; and Tesfay et al. 2013; Meshref 2013; Mohamed and El-Zubier 2007; Bouymajane et al. 2019 for markets sample.

The Results given in (Table 4) revealed that the mean values of the fecal coliform count (FC) in raw milk samples were $9.20 \times 10^{3} \pm 1.82 \times 10^{3}, 6.36 \times 10^{2} \pm 1.9$ $\times 10^{2}, 6.04 \times 10^{3} \pm 1.57 \times 10^{3}, 6.5 \times 10^{3} \pm 1.08 \times 10^{3}$
MPN/ $\mathrm{ml}$ in the examined milk obtained from bulk tank milk, bulk tank milk (after treatment), smallholder dairy herds and milk shops respectively. Lower results were mentioned by Franciosi et al. 2009; Nádia et al. 2012; Belbachir et al. 2015; Titouche et al. 2016 in farm samples; and Dan et al. 2008; Titouche et al. 2016 for markets milk; higher result reported by Ali 2004; Zeinhom 2007; Worku et al. 2012; Ferdous et al. 2017; Bousbia et al. 2018 in farm samples; and Meshref 2013; Seddaoui et al. 2018 for market sample. The results agree with Chorfi et al. 2020 in farm samples and Bouymajane et al. 2019; Mchiouer et al. 2017 for markets sample.

It is evident from the results recorded in (Table 5) that the mean values of E.coli were $2.57 \times 10^{3} \pm 6.11 \times 10^{2}$, $3.8 \times 10^{2} \pm 2.48 \times 10^{2}, 3.89 \times 10^{3} \pm 7.36 \times 10^{2}, 4.15$ $\times 10^{3} \pm 5.44 \times 10^{2} \mathrm{MPN} / \mathrm{ml}$ in the examined milk obtained from bulk tank milk, bulk tank milk (after treatment), smallholder dairy herds and milk shops respectively. Lower results were reported by Pourhassan and Taravat-Najafabadi 2011; Kuma et al. 2015; Kateřina et al. 2016; Mohamed et al. 2017 in farm raw milk; and Belli et al. 2013; Pyz£ukasik et al. 2015; Chimuti et al. 2016; Ntuli et al. 2016; EL-Kholy et al. 2018 in raw market milk; while higher result were mentioned by Ali 2004; Yavarmanesh et al. 2015; Nordin et al. 2019 and Bauzad et al. 2019 in in farm raw milk and Mohamed and El-Zubier 2007; El-Shorbagy et al. 2009; Kassem 2011; Tesfay et al. 2013; Meshref 2013; El nahas et al. 2015; Kuma et al. 2015; Yavarmanesh et al. 2015; Hassan et al. 2021 in market samples; results nearly agree with Tesfay et al. 2013; Mohamed et al. 2017 for farm raw milk; and Ali and Abdelgadir 2011; Fadaei 2014; ElLeboudy et al. 2017 in market samples.

Results of milk samples collected from bulk tank milk of large dairy herds showed TBC ranged from $1.1 \times 10^{5}$ to $9 \times 10^{7}$ with average count $1.53 \times 10^{7} \pm$ $6.27 \times 10^{6} \mathrm{cfu} / \mathrm{ml}$, after improving of the environmental and pre milking sanitation (washing worker hands with soap and clean water before milking, washing the udder with water and drying the udder with a clean dry cloth and teat dipping using iodine component), the TBC of samples showed decrease in count ranging from $1.02 \times 10^{5}$ to $1.1 \times 10^{7}$ with average count $2 \times 10^{6} \pm 6.58 \times 10^{5} \mathrm{cfu} / \mathrm{ml}$, the decline of TBC after treatment agree with those of De Silva et al. (2016). Psychrotrophic bacterial count did not show significant variation before and after 
treatment as TBC where it changed from $2.83 \times 10^{5} \pm$ $6.85 \times 10^{4}$ to $8.98 \times 10^{4} \pm 2.67 \times 10^{4}$, while total coliform count, fecal coliform and E.coli changed as $\left(3.89 \times 10^{5} \pm 1.38 \times 10^{5} \mathrm{MPN} / \mathrm{ml}\right.$ to $5.3 \times 10^{4} \pm 3.07$ x $\left.10^{4} \mathrm{MPN} / \mathrm{ml}\right),\left(9.2 \times 10^{3} \pm 1.82 \times 10^{3} \mathrm{MPN} / \mathrm{ml}\right.$ to $\left.6.36 \times 10^{2} \pm 1.9 \times 10^{2} \mathrm{MPN} / \mathrm{ml}\right)$ and $\left(2.57 \times 10^{3} \pm 6.11\right.$ $\mathrm{x} 10^{2} \mathrm{MPN} / \mathrm{ml}$ to $3.8 \times 10^{2} \pm 3.48 \times 10^{2} \mathrm{MPN} / \mathrm{ml}$ ) respectively.

\section{Conclusion}

The current results allowed to assuming that the sanitary measures adopted during production, handling and processing of raw milk from farmers' houses were not applied and this represents a public health hazard, where all of examined raw milk samples collected from Beni-Suef governorate were contaminated and exceeded the ES 2005 limits for raw milk. Therefore, the application of HACCP system must be adopted in both milk production units, milk products processing plants and during transportation and displaying the final product.

\section{Authors Contributions}

All authors contributed equally to study design methodology, interpretation of results and preparing of the manuscript.

\section{Conflict of interest}

The authors declare no conflict of interest.

\section{References}

Abou Dawood Al, Soada HT, Mohamed MA (2005). Chemical and microbiological quality of raw milk, soft and hard cheese collected from some districts from Zagazig govern Egypt J Dairy sci., 33:201-214.

Acharya S, Bimali NK, Shrestha S, Lekhak B (2018). Bacterial Analysis of Different Types of Milk (Pasteurized, Unpasteurized and Raw Milk) Consumed in Kathmandu Valley. Tribhuvan Univ J Microbiol.. 4: 32-8.

APHA (1992a). Standard methods for the examination of dairy products. $16^{\text {th }}$ Ed., American public health association, Washington.

Banik Sk, Das KK, Uddin MA (2014). Microbiological quality analysis of raw, pasteurized, UHT milk samples collected from different locations in Bangladesh. Stamford J Microbiol.. 4(1):5-8.

Bauzad M, Yuliati F, Prahesti K, Malaka R (2019). Total plate count and Escherichia coli in raw buffalo milk in curio district enrekang regency. IOP Conference Series: Earth and Environmental Sci., 247. 012027. https://doi.org/10.1088/1755-1315/247/1/012027.

Belbachir C, Khamri M, Saalaoui E (2015). Microbiological quality of the raw cow milk at three rural communes of the eastern region of Morocco. Int Food Res J., 22: 1675-1680.
Belli P, Cantafor FA, Stella S, Barbieri S, Crimella C (2013). Microbiological survey of milk and dairy products from a small scale dairy processing unit in Maroua (Cameroon). Food Control, 32: 366-370.

Bousbia A, Boudalia S, Gueroui Y, Belaize B, Meguelati S, Amrouchi M, Ghebache R, Belkheir B, Benidir M (2018). Nutritional and hygienic quality of raw milk intended for consumption in the region of Guelma, Algeria J dairying, foods and home sci., 37: 192-196.

Bouymajane A, Filali FR, Benhallam F, Eddra A, Allaoui AE, Chaiba A, Aboulkacem A, AIT HOU M (2019). Quantitative and qualitative microbial diversity of the raw cow's milk sold by street trading in Meknes, Morocco. Malaysian J Microbiol Morocco, 15: 425-431.

Cempírková R, Mikulová M (2009). Incidence of psychrotrophic lipolytic bacteria in cow's raw milk. Czech J Anim Sci., 54(2): 65-73.

Cempírková R, Mikulová M, Trávníček J (2009). Counts of psychrotrophic lipolytic bacteria in cow's raw milk samples from the aspect of technological quality J Agrobiology, 26: 113-121.

Chimuti S, Midzi N, Njage PK, Mugadza DT (2016). Microbial species of safety concern in milk from informal processors in Harare, Zimbabwe. African J Microbiol Res., 10: 12571262.

Chorfi K, Bendjemana K, Ayachi A, Mahdi F, Bouzidi NA (2020). Effect of using treated wastewater on the bacteriological quality of raw cow's milk: A case of a farm in Northeastern Algeria. African J Microbiol Research., 14(8): 436-446.

Chye FY, Abdulla A, Ayob M (2004). Bacteriological quality and safety of raw milk in Malaysia. Food Microbiol., 21: 535541. https://doi.org/10.1016/j.fm.2003.11.007.

Dahal LR, Nepali DB, Shah R (2010). Total Bacterial Counts of Raw Milk in Eastern Terai of Nepal. J Agricult Environ., 11: 46-50.

Dairy facts (2003): Ed Nutrition information, 13 international dairy foods Assoc Washingaton, DC 12.

Dan SD, Mihaiu M, Rotaru O, Dalea I (2008). Evaluation of microbiological load and configuration of raw milk from collecting centers in CLUJ country. Bulletin USAMV Vet Med. 65: 346-352.

Deepthi G, Siriwardhana B (2021). Evaluation of Microbiological and Compositional Quality of Raw Cow's Milk (Household and Bulk) in Lankapura, Polonnaruwa, Sri Lanka. Europ J Agricult Food Sci., 3: 166-175.

Dhuol KRR, Osman AM (2014). Study on total bacteria count of raw milk produced in the farm of the college of Veterinary Medicine and Animal Production - Sudan University of Science and Technology. Int J Curr Res Aca Rev., 2(1): 1-6.

Ebissa T, Aki A (2017). Bacteriological quality assessment of raw cow's milk in and around Asossa, Ethiopia Biomedicine and Nursing, 3:(3).

EI- Shinawy SH, El Kholy AM, Zeinhom MMA (2020). Quality assurance of yoghurt during processing. Bs vet med J, $6^{\text {th }}$ Sci Conf., 20(1): 188-194.

El-Diasty ME, El- Kaseh MR (2009). Microbiological monitoring of raw milk and yoghurt samples collected from El-Beida city. Arab J Biotech., 12(1): 57-64.

El-Kholy AM, Hassan GM, Shehata AAE, Mohamed EAS (2015). Studies on enteric pathogens in Milk and some Dairt 
products with special reference to salmonella. Egypt J Appl. Sci., 30(6): 55-69.

EL-Kholy A, Hassan H, EL-Shater M, Bakr A (2018). Indicator microorganism as incides of quality for raw milk and some dairy products. Assiut Vet Med J., 64(158): 40-48.

El-Leboudy AA, Amer AA, El-Mohsen SA (2014). Detection of some pathogenic organisms from dairy farm milk. Alexandria J Vet Sci., 44: 111-118.

El-leboudy A, Amer A, EIMakarem H, Ibrahim EK (2017). Chemical and Microbiological Status of Raw Milk Sold at Local Markets. Alexandria J Vet Sci., 55: 125. https://doi.org/10.5455/ajvs.281717.

El-Sayed MA, Hosny IM, El-Kholy WI, El Dairouty RK, Mohamed SHS (2011). Microbiological evaluation of Egyptian white soft cheeses style. Amer Sci J., 7(5): 517- 526.

Elshaghabee FMF, Abdel-Hamid MI, Walte HG (2017). A Survey on Selected Quality Parameters of Buffalo Milk Samples Collected from Consumer Markets of Three Different Central Governorates in Egypt. Milk Sci Int., 70: 25-29.

El-Zubeir IEM, Ahmed MIA (2007). The hygienic quality of raw milk produced by some dairy farms in Khartoum State, Sudan. Res J Microbiol., 2: 988-991.

Egyptian Standards (E.S.) (2005): Milk and dairy products. Raw milk. Egyptian Organization for Standardization and Quality Control, 154.

FAO (2020): Dairy market review. FAO, Rome, ITA. http://www.fao.org/3/ca8341en/CA8341EN.pdf (accessed Jun. 2020) FEDEGAN (Federación Colombiana de Ganaderos). 2019. Fondo nacional del ganado - Fondo de estabilización de precios.

https://www.fedegan.org.co/estadisticas/produccion-0 (consultado 30 mar. 2020).

Ferdous N, Hnini R, Chigr F, Najimi M (2017). Hygienic Quality of Raw Cow Milk Produced by Smallholder Dairy Farmers in BeniMellelarea in Morocco. World J Res Review (WJRR), 5 (I-2): 9-16.

Franciosi E, Pecile A, Cavazza A, Poznanski E (2009). Microbiological monitoring of raw milk from selected farm in the Trentingrana region. Italian J Ani Sci., 8: 408-410.

Gomaa NF, Hashish M, Kassem MM (2008). Quality Assessment of Milk in Alexandria. Bulletin of High Institute of Public Health, 38(2).

Hahne J, Isele D, Berning J, Lipski A. (2019). The contribution of fast growing, psychrotrophic microorganisms on biodiversity of refrigerated raw cow's milk with high bacterial counts and their food spoilage potential. Food Microbiol., 79: 11-19.

Hassan G, Meshref A, Elnewery H, Megawer A (2021). Prevalence of Escherichia coli in Milk and Some Dairy Products in Beni-Suef Governorate, Egypt. J Vet Med Res., 27(2): 161-167.

Hossain TJ, Alam K, Sikdar D (2011). Chemical and microbiological quality assessment of raw and processed liquid market milks of Bangladesh. Res J Dairy Sci., 4(4): 2834.

Ibrahim GA, Sharaf OM, Abd El-Khalek AB (2015). Microbiological Quality of Commercial Raw Milk, Domiati Cheese and Kareish Cheese. Middle East J Applied Sci., 5(1): 171-176.
Ibrahim HA, Abd El Al, S, Tolba MH (2008). Presence and Activity of Psychrotrophic Bacteria in Raw Cow's Milk and Some Dairy Products. $9^{\text {th }}$ Sci Vet Med Conf, Port-Said, 61- 77.

Kuma A, Tolossa D, Abdisa M (2015). Assessment of Raw Milk Microbial Quality at Different Critical Points of Oromia to Milk Retail Centers in Addis Ababa. Food Sci Quality Management, 38.

Kumerasan G, Annalvilli R, Sivakumar K (2007). Psychrotrophic spoilage of raw milk at different temperatures of storage. J Applied Sci Res., 3: 1383-1387.

Lingathurai S, Vellathurai P (2013). Bacteriological quality and safety of raw cow milk in Madurai (South India). Bangladesh J Sci Industrial Res., 48: 109-114.

M'hamdi M, Bouraoui R, Darej C Mahjoub A, Hassayoune L, M'hamdi H, Lanouar L (2018). The Effect of Storage Temperature and Duration on the Composition and Bacteriological Quality of Raw Milk. RRJAAS, 7(1).

Mchiouer K, Bennani S, El-Gendy NSh Meziane M (2017). Evaluation of the Hygienic Quality of RawCow's Milk in Oujda City Morocco. Biosci Biotech Res Asia, 14(2): 587591.

McKillip J, Wang J Q (2017): Short communication: Microbiological quality of raw cow milk and its association with herd management practices in Northern China. J Dairy Sci., 100: 4294-4299.

Mekuria S, Regassa A, Abebe R, Fekade A, Dires B (2014). Bacteriological Study on Rawmilk Collected from Hawassa Smallholder Dairy Farms. Adv Biol Res., 8(5): 194-200.

Meshref AMS (2013). Bacteriological quality and safety of raw cow's milk. Slov Vet Res., 50(1): 21-30.

Metza M, Sheehana J, Feng PCH (2020). Use of indicator bacteria for monitoring sanitary quality of raw milk cheeses - A literature review. Food Microbiol., 85: 103-283.

Mhone TA, Matope G, Saidi PT (2011). Aerobic bacterial, coliform, Escherichia coli and Staphylococcus aureus counts of raw and processed milk from selected smallholder dairy farms of Zimbabwe. Int J Food Microbiol., 151: 223-228.

Nadia M, Diane S, Débora O, Mirlei RE (2012). Evaluation of microbiological quality of raw milk produced at two pin the far West of Santa Catarina, Brasil. Food and Public Health, 2: 79-84.

Nordin Y, Kwan SY, Chang WS, Loo YY, Tan CW, Mohd Fadzil SN and Son R (2019). Evaluation of bacteriological quality of locally produced raw and pasteurized milk in Selangor, Malaysia. Food Res., 3: 208-212.

Nörnberg MF, Friedrich RS, Weiss RD, Tondo EC Brandelli A (2010): Proteolytic activity among psychrotrophic bacteria isolated from refrigerated raw milk. Int J Dairy Technol., 63: 41-46.

Ntuli V, Njage PMK, Buys EM (2016). Characterization of Escherichia coli and other Enterobacteriaceae in producerdistributor bulk milk. J Dairy Sci., 99(12): 9534-9549.

Ombarak R, Elbagory A (2015). Bacteriological quality and safety of raw cow's and buffalo's milk sold in Menoufia governorate, Egypt. Minufiya Vet J., 9: 101-113.

Pinto CLO, Martins ML, Vanetti MCD (2006). Qualidade microbiolo'gica de leite cru refrigerado e isolamento de bacte'rias psicrotro'ficas proteolı́ticas. Cie^ncia eTecnologia de Alimentos, 26: 645-651. 
Rai S, Karki B, Humagain S, Rimal S, Adhikari S, Adhikari S Thapa $S$ (2020). Antibiogram of Escherichia coli and Staphylococcus aureus isolated from milk sold in Kathmandu district. Nepal J Biotechnol., 8(3): 82-86.

Ribeiro Júnior JC, de Oliveira AM, Silva F, de G, Tamanini R, de Oliveira ALM, Beloti V (2018). The main spoilage-related psychrotrophic bacteria in refrigerated raw milk. J Dairy Sci., 101: 75-83.

Saad MF, Nagah MH, Salwa AA (2013). Microbiological quality evaluation of raw goat's milk in Egypt. IJBPAS, 2(10): 18371848.

Seddaoui I, Saada DI, Attou S, Homrani A (2018). Diagnosis of the Quality of Raw Cow's Milk received in the Dairies of Western Algeria. Adv Biores.. 9(2): 166-177.

Senarath HMIGAMK, Adikari AMJB (2017). Microbiological Quality of Raw Milk at Selected Chilling Centers in Anuradhapura District of Sri Lanka, Int J Sci Res Public., 7: 328- 333.

Sraïri MT, Moudnib J, Rahho L, Hamama A (2006). How do milking conditions affect the hygienic quality of raw milk? Case study from Moroccan dairy farms. Livestock Res Rural Development, 18(7): 97.

Tassew A, Seifu E (2011). Microbial quality of raw cow's milk collected from farmers and dairy cooperatives in Bahir Dar Zuria and Mecha district, Ethiopia. Agricult Biol J North America, 2: 29-33.

Tekilegiorgis T (2018). Microbiological Quality Analysis of Raw and Pasteurized Milk Samples Collected from Addis Ababa and Its Surrounding in Ethiopia. Appro Poult Dairy and Vet Sci., 4(5).

Tesfay T, Kebede A, Seifu E (2013). Quality and Safety of Cow Milk Produced and Marketed in Dire Dawa Town, Eastern Ethiopia. Inter J Integrative Sci., Innovation and Technol Section B, (2)6: 1-5.
Titouche Y, Hakem A, Salmi D, Yabrir B, Chenouf N, Chergui A, Houali K (2016). Assessment of microbiological quality of raw milk produced at Tizi Ouzou area (Algeria). Asian J Anim Vet Adv., 11: 854-860.

Tobar-Delgado ME, Rodríguez-Bautista JL, Patiño-Burbano, RE, Argote-Vega FE Castro-Rincón E, Mogollón-García H (2020). Quality of raw milk in the highland tropics of Nariño, Colombia. Agronomía Mesoamericana, 695-707.

Torkar KG, Teger SG (2008). The microbiological quality of raw milk after introducing the two day's milk collecting system. Acta Agric Slovenica 92: 61-74.

Worku T, Negera E, Nurfeta A, Welearegay H (2012). Microbiological quality and safety of raw milk collected from Borana pastoral community, Oromia Regional State. Afr J Food Sci Technol., 3(9): 213-222.

Yeserah B (2019). Microbiological quality of raw cow's milk in and around Bahir Dar City, Ethiopia. Food Sci Quality Management, 88: 1-10.

Zeinhom MMA (2007). Quality assurance of youghurt and raw milk during processing. MVSc Thesis Fac Vet Med Beni-Suef Univ Egypt.

Zhang G, He G (2017). Psychrotrophic bacterial populations in Chinese raw dairy milk. Lwt - Food Sci Technol., 84: 409.

How to cite this article:

Meshref AMS, Hassan GM, Tamam MA. Bacteriological Quality of Raw Milk in Beni-Suef Governorate, Egypt. J Vet Med Res. 2021; 28(2): 45-51.

https://doi.org/10.21608/jvmr.2021.103336.1043 